\title{
Do Social Networking Fan Page Posts Matter for Corporate Image? Modified Elaboration Likelihood Model Perspective
}

\author{
Soo Il Shin, Kennesaw State University, USA \\ Dianne J. Hall, Auburn University, USA \\ Sumin Han, Auburn University, USA \\ David Paradice, Auburn University, USA \\ (iD) https://orcid.org/0000-0002-0287-3249 \\ Teresa Lang, Auburn University at Montgomery, USA
}

\begin{abstract}
The purpose of the current study is to examine factors affecting corporate image driven by social networking fan pages on Facebook. Under the modified elaboration likelihood model (ELM), the authors answer how fan page contributor post quality (FPQ) and source credibility (FPC) influence fan page post informativeness (FPI) and in turn impact corporate image. The authors tested the hypotheses by analyzing survey responses using a covariance-based SEM method from 178 respondents who follow at least one company fan page on Facebook. The findings reveal that FPQ and FPC play a salient role in explaining FPI, which, in turn, impacts the corporate image. The results show that uncertainty about products or services posted on a fan page significantly moderates the relationships among FPQ, FPC, and FPI. Implications and limitations are discussed.
\end{abstract}

\section{KEYWORDS}

CB-SEM, Corporate Image, Elaboration Likelihood Model (ELM), SNS Fan Page, Social Networking Site (SNS)

\section{INTRODUCTION}

Corporate image has been referred to as "the net result of interaction of all experiences, impressions, beliefs, feelings, and knowledge people have about a company, and it is not a single entity" (Kassim $\&$ Souiden, 2007, p. 220). Few would argue that the amount of effort put toward corporate image development and maintenance online has been steadily increasing. Print, radio, and television advertisements all refer to corporate websites and, increasingly, to social networking sites that have been established as introductions to a corporation's offerings of products and services. But despite this corporate investment in developing and sustaining social media engagement with the public, we can find little research proving that the effort positively benefits a firm's corporate image.

Academic attention on corporate image began in the 1950s (Martineau, 1958), and corporate image has been a vital differentiator when products and services in an industry become very similar. Prior studies have acknowledged that corporate image is not a customer's single impression of the 
company's products or services, but rather is an outcome of the overall cumulative impression in the customer's mind formulated from the many diverse aspects of a particular company (Nguyen \& Leblanc, 2001). While building a successful corporate image may take years to accomplish, it can take only an instant to lose the good reputation that this image reflects (Nguyen \& Leblanc, 2001). For example, a massive recall of Toyota vehicles in 2010 caused a substantial monetary loss due to repair and legal costs. However, incurring image costs was particularly significant, because Toyota had successfully maintained a positive corporate image for many years (Elmerraji, 2010).

Corporate image has traditionally been developed through media advertising and has often relied on celebrities' word of mouth (Kim, Lee, \& Prideaux, 2014). However, because more people are connected to online media resources nowadays (e.g., social networks), online media is becoming an increasingly accepted means by corporations with which to build a corporate image. Unlike conventional one-way communication by an organization, exchanging ideas among organizations and customers and pursuing new opinions positively or negatively alters an organization's image (Becker \& Nobre, 2014). Although corporate image has still been a difficult construct to conceptualize (Browning, Gogo, \& Kimmel, 2018), the current study approaches shaping corporate image through the lens of the social networking fan page and then delves deeply into interactions between corporations and customers.

Given the importance of communications to build up an attractive corporate image, we delve deeply into interactions between organizations and customers via social network fan pages. Particularly, we focus on fan page contents as a starting point for examining the interactions between a company and its content viewers. Creating good quality and credible content on fan pages is important because it tends to attract page followers' active involvement. Corporate image is critical in this context because fan pages created by an organization that is perceived as inauthentic will have negative consequences for the organization. A lack of authenticity occurs when corporations cannot provide a sense of community and when readers believe that page posts are not useful because informative posts have been found to be more satisfying and more valuable to information recipients (Ducoffe, 1996). As a communications outlet, a social networking site (SNS) and its fan page are known to be an aggregate of three system aspects: technological, informational, and social systems (Spagnoletti, Resca, \& Sæbø, 2015). This means that such distinct attributes facilitate unique social relationships, deep engagement, increased collaboration under user-generated digital content, and a sharing culture among individual and organizational users (Wakefield \& Wakefield, 2016). Opening an SNS fan page is common among organizations because they are available free of charge, and fans potentially become customers, thus leading to increased profit (Kang, Tang, \& Fiore, 2014).

Since communication between an organization and its customers within fan pages on social networking sites becomes a key driver shaping corporate image, we employed the elaboration likelihood model (ELM) to examine two aspects of page posts: 1) the quality of the post, and 2) the credibility of the post source. The ELM framework has been an excellent theoretical underpinning because of its ability to examine the central and peripheral information processing routes in order to determine attitudinal changes (Bhattacherjee \& Sanford, 2006). The ELM consists of three theoretical components - central routes, peripheral cues, and elaboration likelihood —in an effort to explain the role of influential routes and an individual's cognitive ability when processing information (Bhattacherjee \& Sanford, 2006; Petty \& Cacioppo, 1986). The ELM posits that the central route and peripheral cue differ from each other in terms of how much information recipients put cognitive effort into or how much they rely on the credibility of the information provider in order to process information. We believe that the ELM serves as an applicable theoretical foundation for the current research by allowing us to focus on examining how a particular reader evaluates post quality and the credibility of the post source, which in turn affects corporate image. Additionally, we argue that the quality of the information presented in the post is another factor dependent on post quality and source credibility because it is a reasonable assumption that a company's post usually embeds a promotional message targeted toward its current or potential customers. 
However, ELM was developed at a time well before the advent of the Internet and online communication media in which SNS fan pages obviously did not exist. Also, ELM has typically been applied in settings where the individual is the unit of analysis as both a sender and a receiver. Thus, applying ELM to examine how a corporation communicates with customers in the SNS environment in order to maintain corporate image should be vastly different. In fact, the corporation's digital identity as a communicating entity needs to be defined theoretically before applying ELM.

Broadly speaking, this paper reports the results of a study motivated by two research questions:

RQ1: Do corporate social networking sites contribute positively to corporate image?

RQ2: What factors in social networking sites affect corporate image?

Accordingly, the purpose of our study is to examine factors affecting corporate image and to explore the relationships between those factors in the context of an SNS and its page subscribers, using an ELM theoretical background. In order to achieve our research goal and answer the research questions regarding corporate image, we adopted four construct antecedents with theoretical foundations: fan page contributor post quality (FPQ), fan page contributor source credibility (FPC), fan page post uncertainty (FPU), fan page post informativeness (FPI), and fan page corporate image (FPCI). The following sections review each construct theoretically, and we formulated a research model and specified hypotheses in order to explore the impact of such constructs on corporate image.

Our study contributes to both ELM and corporate image studies, and our theory-based research design offers insights and implications for both academic researchers and practitioners. We note that ELM was developed approximately four decades ago at a time when the creation and maintenance of corporate image was pursued in a vastly different manner than it is today. Obviously, fan pages did not exist, and it is a relatively new phenomenon. However, corporate image as a whole was typically built through the use of celebrity endorsers with "high credibility." Additionally, ELM was developed as a model of message sending and receiving between individuals. The fan page environment relies more on peer endorsements (word-of-mouth) than it does on celebrity endorsers. The message sending also differs in that the message comes from a corporation, as opposed to an individual, thus arising the need for an ELM update. These factors create a gap in our knowledge regarding the applicability of ELM in today's corporate image building environment, and we believe that our study could potentially influence socially-oriented information systems (IS) artifacts.

The current paper proceeds as follows. We first present theoretical work in the areas of organizations as social actors and ELM, and we review the theoretical aspects of perceived informativeness. We then present a research model and hypotheses based on these theoretical arguments. Lastly, we discuss the research methods and results of our data analysis, key findings, and the implications of the current research.

\section{LITERATURE REVIEW}

\section{Elaboration Likelihood Model}

Since communication between an organization and customers within fan pages on social networking sites has become a key driver shaping corporate image, we employed the elaboration likelihood model (ELM) in order to examine two aspects of page posts: 1) fan page contributor post quality (FPQ), and 2) fan page contributor source credibility (FPC). The ELM framework has been an excellent theoretical underpinning because of its ability to examine the central and peripheral information processing routes in order to determine attitudinal changes (Bhattacherjee \& Sanford, 2006). However, ELM was developed at a time well before the advent of the Internet and online communication media, and SNS fan pages obviously did not yet exist. 
In the ELM, the construct of elaboration likelihood plays a moderating role in the relationship between central/peripheral routes and behavior/attitude changes. The term elaboration refers to "the extent to which a person carefully thinks about an argument" (Ho \& Bodoff, 2014, p. 498). Elaboration likelihood is "not a personality trait or an individual difference, but rather a temporal state that may fluctuate with situational contexts and time, even for the same individual" (Bhattacherjee $\&$ Sanford, 2006, p. 809). Because information recipients' abilities and motivations to process information vary, elaborating the central merit of information is constrained based on the personal relevance of the given information. More elaboration likelihood encourages more thoughtful and deliberate processing of information. In contrast, less elaboration likelihood tends to rely more on peripheral routes because of irrelevant experience that the information recipient holds or little willingness to scrutinize information content (Bhattacherjee \& Sanford, 2006).

Though now widely used, the ELM was developed during the mass-media marketing communication days of the 1980s. Thus, looking at a market through a 1980s lens is neither receptive to new technological developments nor reactive to the digital landscape that empowers today's consumers. Since the 1980s, the forms and distribution methods of advertising have changed dramatically, mainly because of the emergence of the Internet. The diversity of online and offline media options and the variants of consumer choice have led to questioning the validity and relevance of the ELM (Kitchen, Kerr, E. Schultz, McColl, \& Pals, 2014).

However, there are reasons to believe that the ELM is still a viable way to understand what occurs in a social networking context. A significant amount of communication occurs on social networking platforms today, and communication is still an activity that involves the perception of a message by a receiver. Perceived message quality is still relevant, as are perceptions of the message sender. Unfortunately, much of the information presented in social networking settings can be characterized as low-quality, and scholars are concerned that the heavy use of social media for "everyday life information-seeking" behaviors may exacerbate problems such as the sharing of misinformation (Sin, 2016).

Social networking engagement is generally measured by the reaction to a post, such as "liking" it or commenting on it. "Liking" a post is not a random act; it involves some consideration of both the post itself and the source of the post. Research shows that the factors that drive social media engagement are generally related to the post's creator, the post's context, and the features of the content (Jaakonmäki et al., 2017). Studies show that younger people use to post content and the reactions of others as factors in judging post quality (Kim \& Sin, 2016). Thus, prior research suggests that social network sites could support both ELM routes to message processing. The evaluation of post content would be related to the deliberative processing route, and reliance on other user activity (posts, "likes," and so forth) would be related to the peripheral processing route. A corporate web page, in contrast, is a less rich medium to study. While the message content still exists to support the ELM notion of deliberative processing, support for the ELM peripheral route is less clear, likely becoming conflated with some notion of "brand" or supported through the existence of icons designating third-party awards for quality or credibility.

\section{Organizations as Social Actors}

A corporate Internet presence may combine the use of both corporate websites and social networking sites. ELM has typically been applied in settings where an individual is the unit of analysis as both a sender and a receiver, rather than a corporation. Thus, one may reasonably ask why ELM can be utilized when a message sender is (or could be perceived to be) a corporate entity. This section addresses the rationale behind this theory selection using the concept of the organization as a social actor.

Although structurally different, both individuals and corporations share social objectives. Under what circumstances can theories of individual behavior be applied to corporations? Staw (1991) suggested that organizations' micro and macro perspectives could be fruitfully blended by generalizing the notion of behavioral dispositions to the organizational level, and he identified three 
arguments for using "micro models" to explain "macro actions." First, the corporate action may be in the hands of a single individual or a small group of individuals. In cases where the individual(s) have a large amount of autonomy, the corporate action is essentially an individual one. Second, a strong leader can inculcate a certain culture into an organization so that the decisions made by individuals throughout the organization reflect the leadership style of the strong leader. Third, even when the first two conditions do not occur, there may still be value in using a micro-level theory as a metaphor for organization-level theory.

In the development of his argument, Staw (1991) indicates a reading of organization theory in which substituting the word "individual" for the word "organization" results in little loss of meaning. As he states:

Consider also institutional theory's central hypotheses that organizations attempt to manage their public image in order to secure external support and legitimacy, and that they readily model their operations after those of other institutions rather than seek the most efficient response (Meyer \& Rowan, 1977). Such reasoning is not too distant from psychological theories of impression management (Schlenker, 1980), social identification (Markus \& Wurf, 1987), and modeling (Bandura, 1978).

The application of concepts and theories from psychology and sociology is commonplace in organizational research (Whetten, Felin, \& King, 2009), and organizations can be thought of as social actors (Highhouse, Brooks, \& Gregarus, 2009). Whetten and his co-authors discuss both vertical theory borrowing, in which concepts developed at one level of analysis are used at a different level of analysis, and horizontal theory borrowing, in which concepts developed in one context are used in a different context. Though they admit that theory borrowing can be problematic, they find that theory borrowing can also be useful as long as "organizational context and level sensitivity" are considered appropriately. Because our study does not aim to develop organizational theory, the constructs of ELM (discussed next) can be applied in the spirit of Staw's analysis (Staw, 1991).

\section{Fan Page Contributor Post Quality and Source Credibility}

We adopted two constructs as antecedents in our research context, named fan page contributor post quality (FPQ) and fan page contributor source credibility (FPC), in order to explain corporate image through SNS fan pages. First, FPQ is defined as the extent to which a post on a fan page is perceived as persuasive, with strong arguments demonstrating informational value about a corporation's products or services. FPQ is rooted in the core dimension of the central route in ELM. Central routes need "thoughtful comprehension of the arguments presented, evaluation of the quality of those arguments, and combination of multiple and sometimes conflicting arguments" when processing information (Bhattacherjee \& Sanford, 2006, p. 808). When processing information under the central route, complex content demands a high degree of critical thinking or significant attention in order to scrutinize the merit of the messages.

FPC indicates whether a post reader perceives a fan page contributor as trustworthy, credible, and knowledgeable and whether or not the contributor appeared to be an expert. FPC stems from peripheral routes of ELM, which involve how recipients of information rely on third-party opinions, reputation, or emotional affinity toward professionals' opinions when processing information. When using peripheral routes, individuals process information with less cognitive effort, a low level of critical thinking, or reduced elaboration of information. FPC in our research is regarded as an operational construct of the peripheral route in the context of SNS fan pages because SNS users tend to be more attracted to posts if the fan page itself is well-known, credible, or popular among the public, or if it is reputable among other SNS users (Swani, Milne, Brown, Assaf, \& Donthu, 2017). 


\section{Perceived Uncertainty}

We employ a construct of uncertainty named FPU as a proxy for the elaboration likelihood construct for the following reasons. Information asymmetry is unavoidable within the information provider and recipient relationship (Pavlou, Liang, \& Xue, 2007). As such, information asymmetry abates the recipients' ability to elaborate upon the core merits of information (Wilson, 1980). Such hidden information acts as the driver of adverse selection or the fear of opportunistic behavior by information providers (Pavlou et al., 2007). Thus, information recipients may seek the remedy of hidden information or fall into the state of decreased elaboration likelihood.

Additionally, uncertainty refers to "the degree to which the future states of the environment cannot be accurately anticipated or predicted due to imperfect information" (Pavlou \& Fygenson, 2006, p.107). Therefore, uncertainty causes people to misunderstand the true quality of messages due to a lack of pre-knowledge of using a product or rendering a service. In our research context, such a temporal mental state tends to influence post readers' ability to process information with regards to the products or services posted on fan pages. If the degree of uncertainty becomes higher, information recipients perceive more chance of facing hidden true quality or the chance of defrauding (Pavlou et al., 2007). Thus, they seek solutions such as gathering further action or high-quality information. In summary, we consider the level of PFU as a salient moderating factor impacting informativeness jointly with ELM constructs. Becoming a moderating factor is reasonable in ELM, particularly in the communication outlet, because of reflecting people's ability to comprehend information and the degree of understanding that determines the level of informativeness through ongoing communication.

\section{Perceived Informativeness}

Informativeness is defined as "the capability to serve necessary information to target users" (Ha, Park, \& Lee, 2014, p. 1136) and "the degree to which the pre-stored message met the informational needs of the partner" (Hoag, Bedrosian, McCoy, \& Johnson, 2004, p. 1274). Informativeness also refers to the ease of information available to its recipient (Chakraborty, Lala, \& Warren, 2002). As its multiple definitions indicate, informativeness is a perceptual construct that is useful or valuable compared with quantifiable informational cues or the quantity of information provided by the resource (Goel \& Prokopec, 2009). Thus, informativeness does not reflect the amount of information available at a certain place, and information overload has little influence on the informational value delivered to the information recipient (Chakraborty et al., 2002).

Prior studies have found that greater informativeness levels bring information recipients greater satisfaction after consuming supplied information or yield more value on the informational content (Ducoffe, 1996). Informativeness was also found to play an important role in decision-making (Ramanan, 2015). In our research context, perceived informativeness, named as FPI captures the degree to which post readers find the presented information useful and valuable. Because perceived information is deemed to be static information in terms of noting availability and visibility, readily accessible messages embedded in posts regarding products or services positively engage the post reader's perception of message informativeness. While prior studies have examined the amount of information termed "inadequate" and "excessive," both levels of information successfully communicate their intended messages (Hoag et al., 2004).

\section{HYPOTHESES AND RESEARCH MODEL}

Based on the theoretical discussion above, we examined the research model in Figure 1. Following prior studies examining personal belief, effects, and intention to use IT under ELM (Zhou, 2012), our study extends the use of ELM in measuring corporate image as human perception.

In "follower-and-followee" communication media (e.g., Twitter, Instagram, or fan pages in SNS) (Zhang \& Peng, 2015), post creators undertake a significant effort toward composing messages to 
promote brand awareness and facilitate communication about the brand via the pages (Swani et al., 2017). A prior study found that strategically crafted posts, including rewards, promotions, and sales, use strong and persuasive language in order to increase advertising effectiveness (Zhang \& Peng, 2015). The high-quality posts composed under an organization's strategic plan are also derived from information completeness, consistency, and accuracy (Susssman \& Siegal, 2003). Thus, the informativeness of posts is more highly perceived as high if a recipient deems the information to be necessary, convincing, containing in-depth content or persuasive messages. Additionally, a high level of post quality is more likely to draw a reader's attention, thus leading him or her to allot much cognitive effort to understand the meaning or intention of the messages.

In our research context, we claim that companies prepare posts per their own strategic plan to approach page followers because the hedonic and functional content on the fan page both play a salient role in inducing SNS users to become fans (Jahn \& Kunz, 2012). The central route involves scrutinizing given information through a cognitive evaluation process toward issue- or message-related arguments (Zhou, 2012). Therefore, under an information processing route in ELM, as represented by FPQ, we claim that those post readers who actively engage their rational judgment and cognitive ability are more likely to identify more usefulness, completeness, and sufficiency regarding the contents in a post. Therefore, we posit:

H1: FPQ as perceived by a page subscriber is positively associated with FPI.

In the context of SNS pages and embedded information in posts, SNS pages exploit a peer-review mechanism (or bidirectional communication) to urge information validity, compared to traditional news media that allows only unidirectional communication (Tsai \& Men, 2013). For example, under an SNS communicating environment, post readers can argue against misleading information or offer new opinions to others, and such a process enables information posted on fan pages to remain validated. Thus, the fundamental functionality of an SNS page strengthens its credibility and trustworthiness in providing cross-check information accuracy.

Prior studies have found that, regardless of informational cues, information recipients make a less cognitive effort if they believe that the information source is credible and trustworthy (Susssman \& Siegal, 2003). A "cognitive-miser" also tends to quickly change his/her perception if others' ratings or opinions are trustworthy (Mackiewicz \& Yeats, 2014). High source credibility stems from the information recipient's reliance on the reputation of the information source, the third party's opinion, or favorable feelings based on prior personal experience (Chen, Chien, Wu, \& Tsai, 2010). If the credibility of a fan page serves as a trustworthy content provider, post readers are more likely to perceive its content as useful, up-to-date, accurate, and complete. Therefore, we posit:

H2: FPC as perceived by a page subscriber is positively associated with FPI.

Prior studies have found that informativeness significantly affects study participants' perceptual changes. For instance, informativeness among online retailers who provide accurate information positively influences a customer's positive perception of products (e.g., satisfaction) (Lin, 2007). Additionally, if people perceive the provided service value as high, they build up a positive corporate image (Hu, Kandampully, \& Juwaheer, 2009).

We claim that the flow of mutual communication among post readers via fan pages creates a better corporate image through social casting, which is defined as a social platform user's effort to exchange ideas or pursue information from other platform users (Becker \& Nobre, 2014). If post content is deemed accurate, up-to-date, and relevant, post readers will be more likely to form a positive image about a content provider. Because fan pages play an important role in providing a 
place of social casting, we hypothesize that perceived informativeness about products or services via fan pages enhances the corporate image. Therefore, we posit that:

H3: FPI on an SNS fan page is positively associated with FPCI

Prior literature has acknowledged that an imbalance of information between two parties incurs information asymmetry (Akerlof, 1970). In our research context, both post uploaders and readers are self-interested parties whose goals are inconsonant with each other. Thus, hidden information in a page post is likely to lead post readers to overestimate the true quality of a product or service. Post readers may have chances to face high opportunistic risk because of exaggerated expressions, unreliable information, and/or unintentional/intentional fraud due to hidden information. Furthermore, the effect of uncertainty gets worse if fan page followers previously experienced overprices or lowquality products or services when compared to their initial expectation because of relying on the information presented in page posts.

Post readers' prior experiences, or any intrinsic uncertainty rooted in hidden information, can inhibit information acquisition and even its processing. Particularly, because perceived informativeness highly relies on information completeness and necessity, the presence of hidden information becomes a hindering factor when elaborating on the trustworthiness of posts. Because hidden information is a driving factor of uncertainty toward products or services, a higher level of uncertainty requires post readers to rely more on the third party's opinion and make a more significant cognitive effort to processing the information. Therefore, we posit:

H4: The degree of FPU regarding products or services positively moderates the relationship between FPQ and FPI (H4a), as well as between FPC and FPI (H4b).

The last hypothesis posits a mediating role of FPI between FPQ/FPC and corporate image. Corporate image has been defined "as a function of the accumulation of purchasing/consumption experience overtime" (Andreassen \& Lindestad, 1998) and has been explained as both the cognitive and affective aspects by individuals associated with a company (Gotsi, Lopez, \& Andriopoulos, 2011). The degree of the corporate image is deteriorated if it loses public confidence or reputation (Vid, 2016).

The current research context conceptualizes FPQ and FPC as cognitive and affective reliance, respectively, when processing information. It means that FPQ and FPC become deteriorating or improve the degree of corporate image because they are determining factors of the information quality and credibility. A prior study has found that the degree of informativeness is represented as how much it offers useful and up-to-date informational content (Lin, 2007) and how much the post contains informational subject matter (Chang, Lu, \& Lin, 2020). Therefore, we claim that corporate image is highly associated with complete, accurate, and credible fan page content if the fan page content is useful and shows up-to-date information. Another prior study has also found significant relationships between ELM constructs and perceived informativeness (PI), and also between PI and emotional response as a form of attitude. It showed a high level of information regarding objects that derive a high degree of people's beliefs or feelings. Such a high level of information is elicited by complete, accurate, and credible information, as well as the involvement of a third party (Chang et al., 2020). Thus, we posit:

H5: FPI mediates relationships between FPQ and FPCI, as well as between FPC and FPCI. 


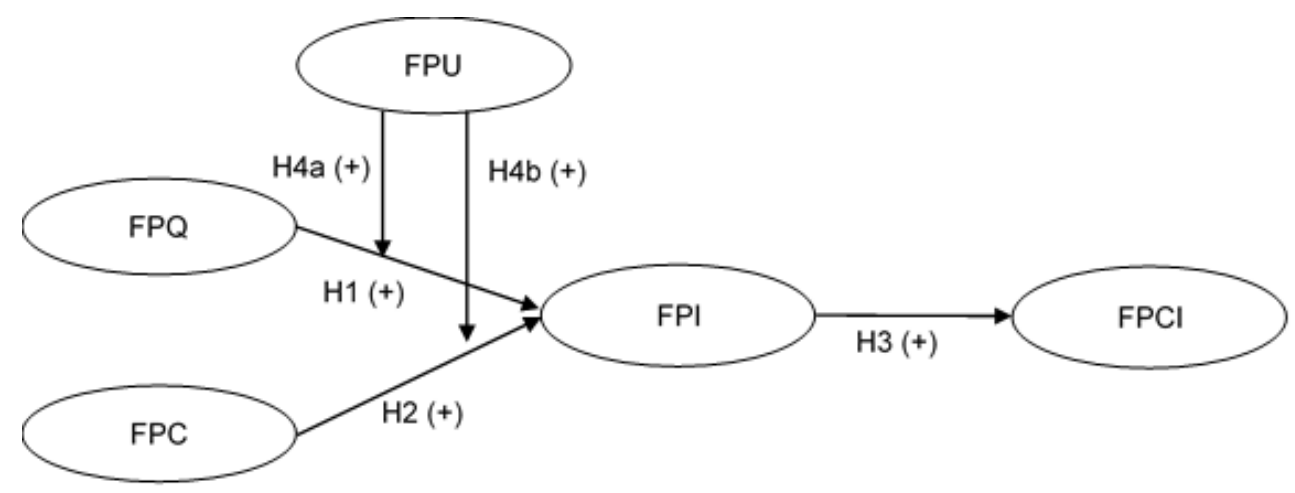

\section{RESEARCH METHOD}

\section{Measurement Items}

We tested our research model and hypotheses using the web-based survey listed in Table 1. All survey questions were adapted from prior studies to suit the current research context. We assessed all survey items via a seven-point Likert scale, ranging from 1 (strongly disagree) to 7 (strongly agree). Also, demographic variables including age, education, income, and SNS engagement characteristics were included as control variables. Four questions were asked about users' frequency and period of Facebook use, the status of page subscriptions, and the number of pages that participants were currently following.

\section{Data Collection}

Before collecting survey responses, we conducted a pilot test with 98 Facebook users who had prior experience with companies' postings or Facebook pages. After collecting the data, all measurement items were revised through the steps of modifications and clarifications. During the main data collection stage, we recruited 178 participants who were public Facebook users and subscribed to at least one company fan page, using a participant pool from Qualtrics (Qualtrics.com). We chose the Skip Logic option in order to gather all answers and ruled out inattentive participants who completed the survey within unreasonable time frames (i.e., less than a minute). Using G*Power 3.1 (Faul, Erdfelder, Buchner, \& Lang, 2009), our final sample size exceeds the minimum sample size of 85 and can detect at least a minimum of the effect size of 0.09 , setting power of 0.80 and an alpha value equal to 0.05 .

Of the participants, $61 \%$ were female, and $39 \%$ were male; $36 \%$ of the participants were $23-39$ years old, $24.7 \%$ were $40-49$ years old, $35.4 \%$ were $50-69$ years old, and $4 \%$ of participants were over 70 years old. More than half of the survey respondents answered that they held at least an associate's college degree or higher (see Table 2).

At the time of the survey, more than $51 \%$ of the participants had been using Facebook for more than five years, while $45 \%$ of participants indicated that they had been using Facebook for between one and five years. Among the survey participants, more than $44 \%$ of total respondents currently "Like" or subscribe to at least 11 or more pages. Additionally, $12.4 \%$ of total respondents read new posts all of the time, and only 9\% rarely read new posts on their "Liked" fan pages. Survey respondents indicated 
Table 1. Measurement items

\begin{tabular}{|c|c|}
\hline Constructs & Measurement Items \\
\hline \multirow{3}{*}{ Facebook Usage } & $\begin{array}{l}\text { Do you use Facebook to communicate with your friends or to get information from companies? } \\
\text { 1. Yes } \\
\text { 2. No }\end{array}$ \\
\hline & $\begin{array}{l}\text { How long have you used Facebook? } \\
\text { 1. More than five years } \\
\text { 2. More than three years but less than five years } \\
\text { 3. More than one year but less than three years } \\
\text { 4. More than six months but less than one year } \\
\text { 5. Less than six months }\end{array}$ \\
\hline & $\begin{array}{l}\text { How often do you log in to Facebook? } \\
\text { 1. Less than once a month } \\
\text { 2. Once a month } \\
\text { 3. } 2-3 \text { times a month } \\
\text { 4. Once a week } \\
\text { 5. } 2 \text { - } 3 \text { times a week } \\
\text { 6. Daily } \\
\text { 7. More than once a day }\end{array}$ \\
\hline \multirow{4}{*}{ Facebook Fan Page } & $\begin{array}{l}\text { Have you ever clicked "Like" or "Subscribe" to indicate that you support any company-managed fan pages on } \\
\text { Facebook? } \\
\text { 1. Yes } \\
\text { 2. No }\end{array}$ \\
\hline & $\begin{array}{l}\text { How many companies have you selected "Like (or Subscribe)" to support on Facebook? } \\
\text { 1. } 1-5 \\
\text { 2. } 6-10 \\
\text { 3. } 11-20 \\
\text { 4. } 20 \text { and more }\end{array}$ \\
\hline & $\begin{array}{l}\text { How many times do you read postings from your "Liked (or Subscribed)" companies when they update information } \\
\text { (i.e. posting product or service information or daily briefings) on their Facebook fan pages? } \\
\text { 1. Never } \\
\text { 2. Rarely } \\
\text { 3. Sometimes } \\
\text { 4. Often } \\
\text { 5. All the time }\end{array}$ \\
\hline & $\begin{array}{l}\text { For what type of companies do you usually click "Like" (or Subscribe)? } \\
\text { 1. Food or dining } \\
\text { 2. Education } \\
\text { 3. Entertainment } \\
\text { 4. Shopping } \\
\text { 5. Travel } \\
\text { 6. Financial Services (i.e., Bank, Credit Card) } \\
\text { 7. Housing } \\
\text { 8. Government, Non-profit organization } \\
\text { 9. Others }\end{array}$ \\
\hline $\begin{array}{l}\text { Fan Page Contributor Post Quality } \\
\text { (Bhattacherjee and Sanford, 2006) }\end{array}$ & $\begin{array}{l}\text { The information provided from companies' Facebook fan pages that I "Liked or Subscribed to" is.... } \\
\text { 1. Informative } \\
\text { 2. Helpful } \\
\text { 3. Valuable } \\
\text { 4. Persuasive }\end{array}$ \\
\hline $\begin{array}{l}\text { Fan Page Contributor Source Credibility } \\
\text { (Bhattacherjee and Sanford, 2006) }\end{array}$ & $\begin{array}{l}\text { My "Liked or Subscribed" companies' Facebook fan pages providing the information... } \\
\text { 1. are knowledgeable on the products or services } \\
\text { 2. are trustworthy } \\
\text { 3. are credible } \\
\text { 4. appears to be an expert on the products or services }\end{array}$ \\
\hline $\begin{array}{l}\text { Fan Page Post Uncertainty } \\
\text { (Pavlou et al., 2007) }\end{array}$ & $\begin{array}{l}\text { After reading a description of products, services or promotional events on companies' Facebook fan pages (that I } \\
\text { "Liked or Subscribed"), } \\
\text { 1. I have confidence the description on postings reduces a degree of uncertainty. } \\
\text { 2. I feel uncertainty associated with the contents on posts is low } \\
\text { 3. There is a low degree of uncertainty when I actually purchase products or contract for services by relying on } \\
\text { companies' Facebook page posts } \\
\text { 4. I am exposed to little transaction uncertainties if I purchase products or render services after reading (or watching, } \\
\text { listening to) companies' posts regarding such products, services or promotional events on their Facebook fan pages } \\
\text { (that I "Liked or Subscribed"). }\end{array}$ \\
\hline Fan Page Post Informativeness (Lin, 2007) & $\begin{array}{l}\text { The companies' posts on their Facebook fan pages that I "Liked or Subscribed to" provide... } \\
\text { 1. Up-to-date information } \\
\text { 2. Accurate information } \\
\text { 3. Useful information } \\
\text { 4. Complete information }\end{array}$ \\
\hline $\begin{array}{l}\text { Fan Page Contributor Corporate Image } \\
\text { (Nguyen and Leblanc, 2001) }\end{array}$ & $\begin{array}{l}\text { 1. I have always had a good impression of the message posting company. } \\
\text { 2. In my opinion, the messaging posting company has a good image in the minds of consumers. } \\
\text { 3. I believe that the message posting company has a better image than its competitors. }\end{array}$ \\
\hline
\end{tabular}


Table 2. Demographic information of survey respondents

\begin{tabular}{|c|c|c|c|}
\hline \multicolumn{2}{|c|}{ Items } & \multirow{2}{*}{$\begin{array}{c}\text { Frequency } \\
69 \\
109\end{array}$} & \multirow{2}{*}{$\begin{array}{c}\text { Percent } \\
38.8 \\
61.2\end{array}$} \\
\hline Gender & $\begin{array}{c}\text { Male } \\
\text { Female }\end{array}$ & & \\
\hline Age & $\begin{array}{c}23-29 \\
30-39 \\
40-49 \\
50-59 \\
60-69 \\
70-\text { Over }\end{array}$ & $\begin{array}{c}19 \\
45 \\
44 \\
32 \\
31 \\
7\end{array}$ & $\begin{array}{l}10.7 \\
25.3 \\
24.7 \\
18.0 \\
17.4 \\
3.9\end{array}$ \\
\hline Education & $\begin{array}{c}\text { Grammar School } \\
\text { High School or equivalent } \\
\text { Vocational/Technical School (2 year) } \\
\text { Some College } \\
\text { College Graduate (4 year) } \\
\text { Master's Degree (MS) } \\
\text { Doctoral Degree (PhD) }\end{array}$ & $\begin{array}{c}1 \\
34 \\
12 \\
61 \\
48 \\
20 \\
2\end{array}$ & $\begin{array}{c}0.6 \\
19.1 \\
6.7 \\
34.3 \\
27.0 \\
11.2 \\
1.1\end{array}$ \\
\hline Household income & $\begin{array}{c}\text { Rather not say } \\
\text { Under } \$ 10,000 \\
\$ 10,000-\$ 19,999 \\
\$ 20,000-\$ 29,999 \\
\$ 30,000-\$ 39,999 \\
\$ 40,000-\$ 49,999 \\
\$ 50,000-\$ 74,999 \\
\$ 75,000-\$ 99,999 \\
\$ 100,000-\$ 150,000 \\
\text { Over } \$ 150,000\end{array}$ & $\begin{array}{c}9 \\
8 \\
13 \\
23 \\
26 \\
17 \\
35 \\
24 \\
17 \\
6\end{array}$ & $\begin{array}{c}5.1 \\
4.5 \\
7.3 \\
12.9 \\
14.6 \\
9.6 \\
19.7 \\
13.5 \\
9.6 \\
3.4\end{array}$ \\
\hline
\end{tabular}

that food and dining fan pages were the respondents' top selections, followed by entertainment and shopping-related fan pages (see Table 3).

\section{RESULTS}

\section{Common Method Bias}

Since the items of the constructs in the research framework were collected in the same questionnaire, common method bias can be an issue. Therefore, two statistical tests were conducted in order to avoid concerns about the common method bias. First, Harman's single-factor test (Podsakoff, MacKenzie, Lee, \& Podsakoff, 2003) using an unrotated exploratory factor analysis was conducted, which revealed five factors that emerged. The first factor in the exploratory factor analysis accounted for $27.7 \%$ of the total variance, which is below the recommended cutoff point of $50 \%$ among the variables. We compared the five-factor model to a common latent factor model, and the results indicated that the model with five factors $\left(\chi^{2}=330.04, d f=131, \chi^{2} / d f=2.55\right.$, GFI=0.89, CFI=0.94, RMSEA=0.09) performed better than the common latent factor model $\left(\chi^{2}=944.96, d f=152, \chi^{2} / d f=6.22, \mathrm{GFI}=0.68\right.$, $\mathrm{CFI}=0.71$, RMSEA=0.18). Second, a common latent factor analysis (Lowry \& Gaskin, 2014) was performed. The standardized regression weights of all variables in the measurement model were calculated after adding the common latent factor, and these scores were compared with the standardized regression weights of all variables (without the common latent factor). The results indicated that the path coefficients of the substantive model are significantly higher than the path coefficients of the common method factor model (the differences are greater than 0.10 ), and these results illustrate that the common method bias does not appear to be a problem in our study (see Table 4). 
Table 3. Facebook usage

\begin{tabular}{|c|c|c|c|}
\hline \multicolumn{2}{|c|}{ Items } & Frequency & Percent \\
\hline $\begin{array}{c}\text { Frequency of } \\
\text { logging into } \\
\text { Facebook }\end{array}$ & $\begin{array}{c}\text { Once a Month } \\
\text { 2-3 Times a Month } \\
\text { Once a Week } \\
\text { 2-3 Times a Week } \\
\text { Daily } \\
\text { More than once a day }\end{array}$ & $\begin{array}{c}2 \\
3 \\
7 \\
17 \\
66 \\
83\end{array}$ & $\begin{array}{c}1.1 \\
1.7 \\
3.9 \\
9.6 \\
37.1 \\
46.6\end{array}$ \\
\hline $\begin{array}{l}\text { Experience of } \\
\text { using Facebook }\end{array}$ & $\begin{array}{l}\text { More than } 5 \text { years } \\
3-5 \text { years } \\
1-3 \text { years } \\
6 \text { months }-1 \text { year } \\
\text { Less than } 6 \text { months }\end{array}$ & $\begin{array}{c}90 \\
59 \\
22 \\
4 \\
3\end{array}$ & $\begin{array}{c}50.6 \\
33.1 \\
12.4 \\
2.2 \\
1.7\end{array}$ \\
\hline $\begin{array}{c}\text { Number of } \\
\text { subscribing fan } \\
\text { pages }\end{array}$ & $\begin{array}{c}1-5 \\
6-10 \\
11-20 \\
20 \text { and more }\end{array}$ & $\begin{array}{l}40 \\
59 \\
38 \\
41\end{array}$ & $\begin{array}{l}22.5 \\
33.1 \\
21.3 \\
23.0\end{array}$ \\
\hline $\begin{array}{l}\text { Frequency of } \\
\text { reading posts }\end{array}$ & $\begin{array}{c}\text { Never } \\
\text { Rarely } \\
\text { Sometimes } \\
\text { Often } \\
\text { All the time }\end{array}$ & $\begin{array}{c}3 \\
16 \\
72 \\
65 \\
22\end{array}$ & $\begin{array}{c}1.7 \\
9.0 \\
40.4 \\
36.5 \\
12.4\end{array}$ \\
\hline \multicolumn{2}{|c|}{ Types of chosen fan page } & \multicolumn{2}{|c|}{ Number of selections } \\
\hline \multicolumn{2}{|c|}{ Food and dining } & \multicolumn{2}{|c|}{141} \\
\hline \multicolumn{2}{|c|}{ Education } & \multicolumn{2}{|c|}{47} \\
\hline \multicolumn{2}{|c|}{ Entertainment } & \multicolumn{2}{|c|}{121} \\
\hline \multicolumn{2}{|c|}{ Shopping } & \multicolumn{2}{|c|}{124} \\
\hline \multicolumn{2}{|c|}{ Travel } & \multicolumn{2}{|c|}{58} \\
\hline \multicolumn{2}{|c|}{$\begin{array}{l}\text { Financial service (e.g., Credit card, } \\
\text { banking) }\end{array}$} & \multicolumn{2}{|c|}{43} \\
\hline \multicolumn{2}{|c|}{ Housing } & \multicolumn{2}{|c|}{26} \\
\hline \multicolumn{2}{|c|}{ Others } & \multicolumn{2}{|c|}{51} \\
\hline \multicolumn{2}{|c|}{$\begin{array}{l}\text { Government or non-profit } \\
\text { organization }\end{array}$} & \multicolumn{2}{|c|}{32} \\
\hline
\end{tabular}

\section{Hypotheses Testing}

Descriptive statistics of the variables, including categorical variables, as well as convergent and discriminant, are presented in Table 5 and Table 6. All values of Cronbach's alpha, composite reliability, and average variance that were extracted indicate that no convergent validity issues have been found (Hair, Black, Babin, Anderson, \& Tatham, 2006).

The Heterotraint-Monotrait (HTMT) values are also shown as less than 0.9 of the recommended criteria, and the square root of the AVEs are greater than the construct correlations. Thus, there appears to be no discriminant validity issue in our study (Hair Jr, Hult, Ringle, \& Sarstedt, 2016; Henseler, Ringle, \& Sarstedt, 2015).

We used structural equation modeling (SEM) that enabled us to simultaneously test all hypothesized relationships, including the direct effects and moderating effects (Chin, 1998). Within SEM, we employed the covariance-based structural equation modeling (CB-SEM) technique over partial least squares (PLS) for several reasons. According to Hair et al. (2014), CB-SEM is more 
Table 4. A Common latent factor model

\begin{tabular}{|c|c|c|c|}
\hline Construct & Indicator & Substantive Factor Loading & Method Factor Loading \\
\hline \multirow{4}{*}{$\begin{array}{l}\text { Fan Page Contributor Post Quality } \\
\text { (FPQ) }\end{array}$} & FPQ1 & 0.803 & 0.086 \\
\hline & FPQ2 & 0.893 & 0.181 \\
\hline & FPQ3 & 0.880 & 0.315 \\
\hline & FPQ4 & 0.797 & 0.306 \\
\hline \multirow{4}{*}{ Fan Page Contributor Credibility (FPC) } & FPC1 & 0.877 & 0.082 \\
\hline & FPC2 & 0.916 & 0.208 \\
\hline & FPC3 & 0.911 & 0.229 \\
\hline & FPC4 & 0.825 & 0.285 \\
\hline \multirow{4}{*}{ Fan Page Post Uncertainty (FPU) } & FPU1 & 0.734 & 0.064 \\
\hline & FPU2 & 0.713 & 0.314 \\
\hline & FPU3 & 0.848 & 0.312 \\
\hline & FPU4 & 0.704 & 0.271 \\
\hline \multirow{4}{*}{ Fan Page Post Informativeness (FPI) } & FPI1 & 0.841 & 0.213 \\
\hline & FPI2 & 0.874 & 0.283 \\
\hline & FPI3 & 0.842 & 0.227 \\
\hline & FPI4 & 0.861 & 0.286 \\
\hline \multirow{3}{*}{$\begin{array}{l}\text { Fan Page Contributor Corporate Image } \\
\text { (FPCI) }\end{array}$} & FPCI1 & 0.831 & 0.255 \\
\hline & FPCI2 & 0.877 & 0.240 \\
\hline & FPCI3 & 0.798 & 0.176 \\
\hline
\end{tabular}

Table 5. Convergent and Discriminant Validity Test

\begin{tabular}{|l|c|c|c|c|c|c|c|c|c|c|}
\hline \multirow{2}{*}{ Construct } & \multirow{2}{*}{ Mean } & S.D. & Cronbach's & \multirow{2}{*}{ C.R. } & \multirow{2}{*}{ AVE } & \multicolumn{5}{|c|}{ Correlation } \\
\cline { 7 - 12 } & & & & & & (1) & (2) & (3) & (4) & (5) \\
\hline (1) FPQ & 5.14 & 4.24 & 0.91 & 0.91 & 0.78 & $\mathbf{0 . 8 8}$ & & & & \\
\hline (2) FPC & 5.13 & 3.94 & 0.92 & 0.92 & 0.80 & 0.71 & $\mathbf{0 . 8 9}$ & & & \\
\hline (3) FPU & 4.55 & 3.87 & 0.83 & 0.85 & 0.66 & 0.79 & 0.78 & $\mathbf{0 . 8 1}$ & & \\
\hline (4) FPI & 5.33 & 3.94 & 0.92 & 0.92 & 0.80 & 0.66 & 0.71 & 0.64 & $\mathbf{0 . 8 9}$ & \\
\hline (5) FPCI & 5.18 & 3.01 & 0.87 & 0.87 & 0.79 & 0.67 & 0.66 & 0.67 & 0.79 & $\mathbf{0 . 8 9}$ \\
\hline
\end{tabular}

Note: Bold numbers in the diagonal indicate the square root of constructs' average variance extracted (AVE).

Table 6. Heterotrait-Monotrait (HTMT) Ratio

\begin{tabular}{|c|c|c|c|c|}
\hline & FPCI & FPC & FPI & FPQ \\
\hline FPC & 0.737 & & & \\
\hline FPI & 0.887 & 0.775 & & \\
\hline FPQ & 0.760 & 0.789 & 0.735 & 0.634 \\
\hline FPU & 0.592 & 0.547 & 0.528 & \\
\hline
\end{tabular}


Table 7. CB-SEM and hypothesis testing results

\begin{tabular}{|c|c|c|c|c|}
\hline \multicolumn{2}{|c|}{ Path } & Coefficient value & $p$-value & Empirical evidence \\
\hline FPQ FPI & $\mathrm{H} 1$ & 0.637 & $<0.000$ & Supported \\
\hline FPC FPI & $\mathrm{H} 2$ & 0.586 & $<0.000$ & Supported \\
\hline FPI FPCI & $\mathrm{H} 3$ & 0.901 & $<0.000$ & Supported \\
\hline FPQ $\times$ FPU FPI & $\mathrm{H} 4 \mathrm{a}$ & 0.119 & $<0.000$ & Supported \\
\hline FPCXFPU FPI & $\mathrm{H} 4 \mathrm{~b}$ & 0.195 & $<0.000$ & Supported \\
\hline
\end{tabular}

appropriate for testing theory. CB-SEM was initially established as a confirmatory approach for testing or disconfirming relationships between theory-based latent constructs (Babin \& Svensson, 2012; Gefen et al., 2011; Shook et al., 2004), while PLS-SEM is primarily intended for an exploratory approach to build new theory in a situation of high complexity with a low level of theory information (Hair et al., 2014). In addition, CB-SEM provides lower bias on parameter estimation and has a higher consistency than PLS-SEM (i.e., CB-SEM is robust with higher accuracy) (Sarstedt et al., 2016; Reinartz et al., 2009). Lastly, CB-SEM is more appropriate when a dataset is distributed as (approximately) normal and satisfies a minimum sample size (Li \& Wang, 2018). CB-SEM estimates a parameter using both the theoretical covariance matrix and the estimated covariance matrix. The goal of CB-SEM is to minimize the difference between the theoretical covariance matrix and the estimated covariance matrix using a maximum likelihood procedure and to maximize explained variance (Hair et al., 2014; Chen, 2012).

The CB-SEM model produces a good fit with the data $\left(\chi^{2}=520.89, d f=165, \chi^{2} / d f=3.16, \mathrm{NFI}=0.94\right.$, $\mathrm{TLI}=0.92, \mathrm{CFI}=0.96$, RMSEA=0.07) as satisfying the recommend cut-off values (Awang, 2012; Forza \& Filippini, 1998; Hair et al., 2011; Hu \& Bentler, 1999; Kenney et al., 2015; Wu et al., 2009).

The hypothesis testing results are shown in Table 7 . We found that there are positive direct effects of FPQ $(\beta=0.637, p<0.000)$ and FPC $(\beta=0.586, p<0.000)$ on FPI, supporting both H1 and H2. Hypothesis 3 is also supported, as consistent with the literature, FPCI is positively and significantly influenced by FPI $(\beta=0.901, p<0.000)$, explaining $69.8 \%$ of its variance $\left(R^{2}=0.704 ;\right.$ adj. $\left.R^{2}=0.698\right)$. FPU is observed significantly and positively moderate the relationship between FPQ and FPI ( $\beta=$ $0.119, p<0.000)$, as well as between FPC and FPI $(\beta=0.195, p<0.000)$, explaining $56.3 \%$ of its variance $\left(R^{2}=0.583\right.$; adj. $\left.R^{2}=0.563\right)$. Thus, $\mathrm{H} 4$ is supported.

Figures 3 and 4 show a closer examination of the significant interaction effect of FPU on FPI. We found that FPU moderates the relationship between FPQ and FPI such that the relationship is stronger when FPU is low than when it is high. Similarly, FPU positively moderated the effect of FPC on FPI. However, the relationship between FPC and FPI is stronger when FPU is high than when it is low.

We conducted a mediation analysis (Preacher et al., 2007) to test H5 (see Table 8). In order to assess the indirect effect estimates, we implemented the bootstrapping procedure presented with the SAS macro and the number of bootstrap resampling techniques. Our results show significant mediating effects of FPQ and FPC on FPI, which means, in turn, that FPI significantly influences corporate image. Both the indirect effect $\left(\beta_{\text {indirect }}=0.295, p<0.000\right)$ and the direct effect $\left(\beta_{\text {direct }}=0.187, p<\right.$ 0.000) of FPQ have the same direction with positive coefficients, and the confidence interval of the indirect effect does not include zero. Therefore, the association between FPQ and corporate image can explain the effects of fan page post informativeness both with and without mediation. Like FPQ, the indirect effect $\left(\beta_{\text {indirect }}=0.360, p<0.000\right)$ and direct effect $\left(\beta_{\text {direct }}=0.144, p<0.000\right)$ of PFC are both in the positive direction, and both effects are significant. These results indicate that the association between FPC and corporate image can explain the effects of FPI with and without mediation. Thus, H5 is supported 
Figure 2. Results of hypotheses test using CB-SEM

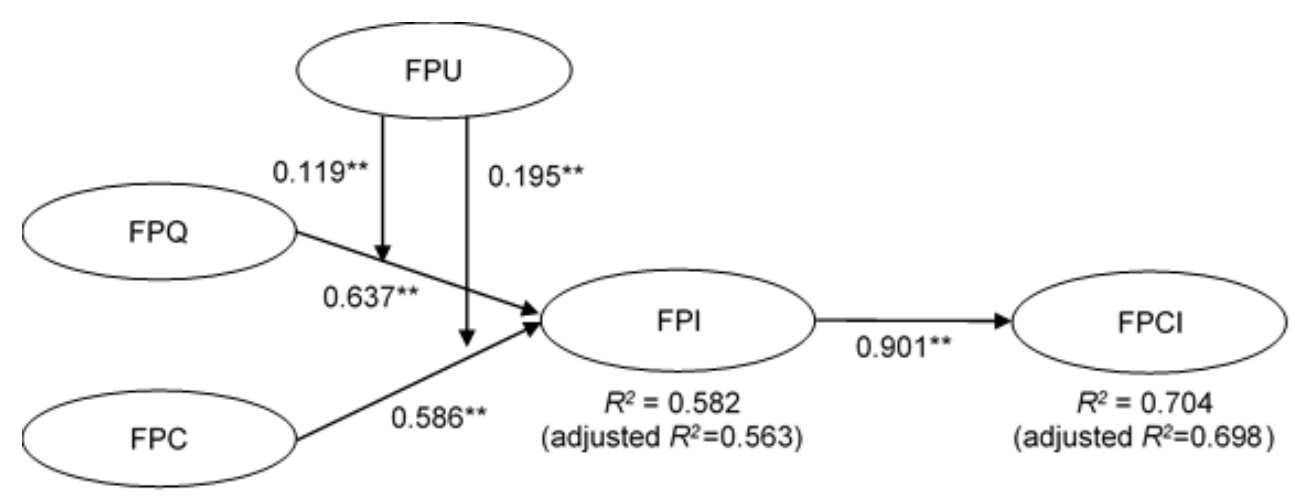

Figure 3. Moderating effect of uncertainty on FPQ (H4a and $\mathrm{H} 4 \mathrm{~b})$

Interaction Effect of Fan Page Post Uncertainty on Fan Page Post Informativeness

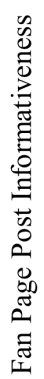

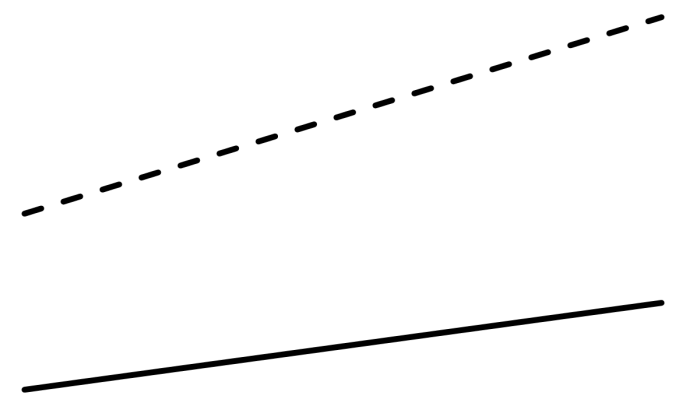

Low Fan Page Post Quality

- Low Fan Page Post Uncertainty
High Fan Page Post Quality

- High Fan Page Post Uncertainty 


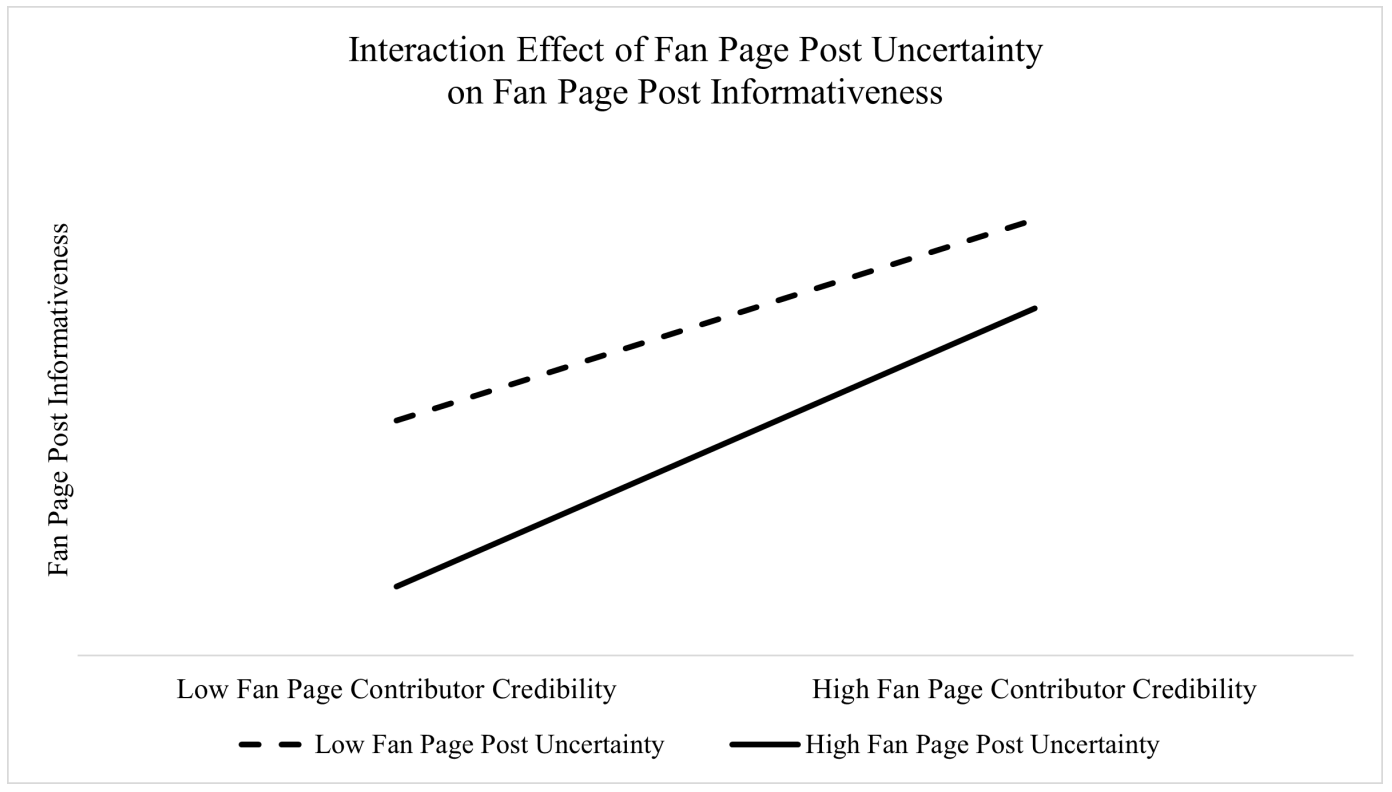

Table 8. Moderated Mediation assessment

\begin{tabular}{|c|c|c|c|c|c|c|c|c|c|}
\hline \multirow[t]{2}{*}{$\begin{array}{l}\text { Predictor } \\
\text { (X) }\end{array}$} & \multirow[t]{2}{*}{$\begin{array}{l}\text { Mediator } \\
\text { (M) }\end{array}$} & \multirow[t]{2}{*}{$\begin{array}{l}\text { Outcome } \\
\text { (Y) }\end{array}$} & \multirow[t]{2}{*}{$\mathbf{X M}$} & \multirow[t]{2}{*}{ MY } & \multirow[t]{2}{*}{$\begin{array}{c}\text { Direct } \\
\text { Path } \\
\text { XY }\end{array}$} & \multirow[t]{2}{*}{$\begin{array}{c}\text { Bootstrapping } \\
\text { for Indirect } \\
\text { Path } \\
\text { XMY }\end{array}$} & \multicolumn{2}{|c|}{$\begin{array}{c}\text { Bias corrected } \\
\text { and accelerated } \\
\text { 95\% Confidence } \\
\text { Interval of } \\
\text { Indirect Path }\end{array}$} & \multirow[t]{2}{*}{$\begin{array}{c}\text { Type of } \\
\text { Mediation }\end{array}$} \\
\hline & & & & & & & $\begin{array}{l}\text { Lower } \\
\text { Limit }\end{array}$ & $\begin{array}{l}\text { Upper } \\
\text { Limit }\end{array}$ & \\
\hline FPQ & FPI & FPCI & $0.622 * *$ & $0.470 * *$ & $0.187^{* *}$ & $0.295^{* *}$ & 0.225 & 0.373 & Complementary \\
\hline FPC & FPI & FPCI & $0.710^{* *}$ & $0.502 * *$ & $0.144 * *$ & $0.360^{* * *}$ & 0.277 & 0.449 & Complementary \\
\hline
\end{tabular}

Note: ${ }^{* *} p<0.000$

\section{DISCUSSION AND IMPLICATIONS}

\section{Key Findings}

In reference to $\mathrm{H} 1$ and $\mathrm{H} 2$, our findings show that not only does post quality induce an enhanced perception of informativeness, but high page credibility itself also plays a salient role in boosting the level of informativeness. Our results are partially consistent with a recent prior study in the context of Facebook Marketplace, in which communication is a core aspect. For example, a prior study showed that ELM's central route significantly affected perceived informativeness, but the peripheral route did not (Chang et al., 2020). However, our study shows that both routes are theoretically meaningful and critical antecedents to explaining the formation of informativeness perception.

Our results reveal a significant relationship between FPI and FPCI. Our findings can be explained by the nature of informativeness, which has been a salient factor affecting the personal hedonic aspect, such as attitude or cognitive value, in the context of social networking sites and website (Chakraborty, Lala, \& Warren, 2002; Ha, Park, \& Lee, 2014; Zha, Li, \& Yan, 2015). As hypothesized in H3, 
high informativeness further enhances corporate image when a company promotes a great deal of communicative and useful posts via fan pages, and it also results in the creation of favorable feelings towards the company overall. Because FPI does not rely on the quantity of information, increasing the number of posts does not always aid in shaping a favorable FPCI. Rather, even a single post that contains accurate information has a greater impact on corporate image than a large number of meaningless posts. Thus, our findings suggest follow-up research to examine whether informativeness accounts for FPCI when the number of informational cues is controlled for.

In reference to H4, our results reveal a significant interaction effect between FPQ / FPC and the level of uncertainty. It is an interesting finding that "low-uncertainty" strengthens the relationship between FPQ and FPI, as well as between FPC and FPI. In other words, if the degree of uncertainty becomes higher, the relationship becomes weaker. Our results are consistent with the notion that the uncertainty of products or services described by a post on a fan page potentially abates the willingness to comprehend the true meaning through information processing routes. The low level of uncertainty interacting with a high FPQ tends to make people deem information on a post to be accurate, up-todate, and useful. The low level of uncertainty interacting with a high FPC tends to make post readers feel little transaction risk afterward. Our study provides meaningful insight in that the uncertainty becomes a significant moderator in the ELM framework, which a prior study did not consider in a similar research context (Chang et al., 2020).

In reference to H5, our analysis shows that the mediation links between FPQ/FPC-FPI-and FPCI are significant, and perceived informativeness is considered as a complementary mediator. Our analysis indicates that both FPQ and FPC cannot be sole antecedents, and therefore they do not offer conclusions about shaping corporate image without the step of perceiving the informativeness of post content. Thus, another hidden mediator may exist, which our current research has not yet considered (Hair, Black, Babin, Anderson, \& Tatham, 2006). Prior studies suggest other influential constructs, including people's prior experience and cumulative impressions, indicating that future research incorporates such perceptions into a mediating effect (Kassim \& Souiden, 2007). In CognitiveAttitude-Behavior mediating relationships, prior studies have suggested variations of three dimensions (e.g., C-A-A, C-B-A, and so on) within different research contexts (Holbrook \& Batra, 1987). Since our mediating relationships are not yet completely explained-at least in our research context-future research suggests employing another construct with variations for a complete explanation of the corporate image.

\section{Theoretical and Practical Implications}

Our research contributes to both ELM and corporate image research in various theoretical ways. First, unlike a conventional ELM adoption research context, our research considers the unique environment of information flow from the message sender (i.e., the corporation) to the message receivers who voluntarily choose to receive this messaging (fans). We synchronized the concept of social actors from the organization theory as theory borrowing. Prior studies have acknowledged that social networking sites are unique communication outlets, resulting in the need to incorporate theories that are directly related to technology or mechanism aspects (Zha, Yang, Yan, Liu, \& Huang, 2018). In ELM studies in the context of social networking sites, few studies have delved into defining the messaging parties under a solid theoretical underpinning before incorporating them into the ELM framework. We fill this research gap by clearly and appropriately defining a message creator and sender through the lens of organizations as social actors. Second, we claimed the need for a new approach in the context of social networking sites and their fan pages in order to examine information processing under the ELM perspective. Employing the construct of uncertainty has led to meaningful findings in our research. In our research context, two-way communication enables users to update new information easily and almost instantly since current social media outlets alarm their subscribers when new information becomes available. Such a facet becomes a significant indicator of ELM's theoretical amendment. Our results indicate that information asymmetry, imbalance, and any hidden information behind a post are 
each likely to influence a post reader's ability to comprehend information. In other words, imperfect information can hinder the willingness to process information in the current research setting. Thus, our research suggests that the use of ELM and its core constructs should be revised, particularly in the current social networking site outlets.

From a practitioner perspective, our findings suggest that practitioners should raise FPQ so that genuine information, rather than opportunistic informational hooks, can be achieved. Additionally, per the significance of FPC, page owners on SNSs may need to pay more attention to maintaining the credibility of a page, along with keeping information quality high. In terms of incorporating the possibility of artificial intelligence (AI), responding to followers or the public immediately regarding any ambiguous information posted on a fan page may assure the credibility of the page itself, as well as legitimize the followers or posters on fan pages. In turn, reducing uncertainty and improving informativeness will tend to shape a good corporate image. Credibility is not an outcome of a shortterm relationship between a company and its customers and is instead built up over time. Recent survey responses from 500 employees working in companies of all sizes emphasized the importance of having CEOs actively involved with SNS, as they believe that such activities promote their brand as highly trustworthy (Brandfog, 2016). Our research findings indicate that a high level of credibility boosts the corporate image perceived by page followers. Thus, managers' active engagement is essential to encouraging a more robust corporate image when a company uses an SNS.

\section{LIMITATIONS AND FUTURE RESEARCH}

As with any study, our research has some limitations. First, we designed the survey items to focus on the content posted on fan pages only in order to measure uncertainty against services or products. The survey questions guided participants to pay attention to posts only on the fan pages evaluating products or services; therefore, considering other external factors (e.g., the popularity of posts) that have influenced uncertainty is necessary. Second, we did not specify what type of products or services (e.g., search goods or experience goods; books or clothing) were mentioned in the posts that were analyzed, nor did we count the number of posts regarding a particular product that was available to page subscribers within a specific time window. Furthermore, page posts regarding search goods do not necessarily need to be persuasive; those messages could be for information purposes only. Therefore, future research should examine how the corporate image is influenced by central and peripheral routes depending on the different types of products or services and the extent of post-exposure. 


\section{REFERENCES}

Akerlof, G. A. (1970). The market for" lemons": Quality uncertainty and the market mechanism. The Quarterly Journal of Economics, 84(3), 488-500. doi:10.2307/1879431

Andreassen, T. W., \& Lindestad, B. (1998). The effect of corporate image in the formation of customer loyalty. Journal of Service Research, 1(1), 82-92. doi:10.1177/109467059800100107

Awang, Z. (2012). Research methodology and data analysis (2nd ed.). UiTM Press.

Babin, B. J., \& Svensson, G. (2012). Structural equation modeling in social science research. European Business Review, 24(4), 320-330. doi:10.1108/09555341211242132

Bandura, A. (1978). Social learning theory of aggression. Journal of Communication, 28(3), 12-29. doi:10.1111/j.1460-2466.1978.tb01621.x PMID:690254

Becker, K., \& Nobre, H. (2014). Social network reputation management: An international study. Journal of Promotion Management, 20(4), 436-451. doi:10.1080/10496491.2014.930282

Bhattacherjee, A., \& Sanford, C. (2006). Influence processes for information technology acceptance: An elaboration likelihood model. Management Information Systems Quarterly, 30(4), 805-825. doi:10.2307/25148755

Brandfog. (2016). CEOs, social media, \& brand reputation. Academic Press.

Browning, N., Gogo, O., \& Kimmel, M. (2018). Comprehending CSR messages: Applying the elaboration likelihood model. Corporate Communications, 23(1), 17-34. doi:10.1108/CCIJ-07-2017-0068

Chakraborty, G., Lala, V., \& Warren, D. (2002). An empirical investigation of antecedents of B2B Websites' effectiveness. Journal of Interactive Marketing, 16(4), 51-72. doi:10.1002/dir.10044

Chang, H. H., Lu, Y.-Y., \& Lin, S. C. (2020). An elaboration likelihood model of consumer respond action to facebook second-hand marketplace: Impulsiveness as a moderator. Information \& Management, 57(2), 103171. doi:10.1016/j.im.2019.103171

Chen, X., \& Siau, K. (2012). Effect of business intelligence and IT infrastructure flexibility on organizational agility. Academic Press.

Chen, Y.-H., Chien, S.-H., Wu, J.-J., \& Tsai, P.-Y. (2010). Impact of Signals and Experience on Trust and Trusting Behavior. Cyberpsychology, Behavior, and Social Networking, 13(5), 539-546. doi:10.1089/cyber.2009.0188 PMID:20950178

Chin, W. W. (1998). The partial least squares approach to structural equation modeling. Modern Methods for Business Research, 295(2), 295-336.

Ducoffe, R. H. (1996). Advertising value and advertising the web. Journal of Advertising Research, 36(5), 21-35.

Elmerraji, J. (2010). The cost of an autor recall. https://www.investopedia.com/financial-edge/0210/the-costof-an-auto-recall.aspx

Faul, F., Erdfelder, E., Buchner, A., \& Lang, A.-G. (2009). Statistical power analyses using G* Power 3.1: Tests for correlation and regression analyses. Behavior Research Methods, 41(4), 1149-1160. doi:10.3758/ BRM.41.4.1149 PMID:19897823

Forza, C., \& Filippini, R. (1998). TQM impact on quality conformance and customer satisfaction: A causal model. International Journal of Production Economics, 55(1), 1-20. doi:10.1016/S0925-5273(98)00007-3

Gefen, D., Rigdon, E. E., \& Straub, D. (2011). Editor's comments: An update and extension to SEM guidelines for administrative and social science research. Management Information Systems Quarterly, 35(2), iii-xiv. doi: $10.2307 / 23044042$

Goel, L., \& Prokopec, S. (2009). If you build it will they come?-An empirical investigation of consumer perceptions and strategy in virtual worlds. Electronic Commerce Research, 9(1), 115-134. doi:10.1007/s10660009-9031-7 
Gotsi, M., Lopez, C., \& Andriopoulos, C. (2011). Building country image through corporate image: Exploring the factors that influence the image transfer. Journal of Strategic Marketing, 19(3), 255-272. doi:10.1080/096 5254X.2011.581387

Ha, Y. W., Park, M.-C., \& Lee, E. (2014). A framework for mobile SNS advertising effectiveness: User perceptions and behaviour perspective. Behaviour \& Information Technology, 33(12), 1333-1346. doi:10.108 0/0144929X.2014.928906

Hair, F. Jr, Ringle, C. M., \& Sarstedt, M. (2011). PLS-SEM: Indeed a silver bullet. Journal of Marketing Theory and Practice, 19(2), 139-152. doi:10.2753/MTP1069-6679190202

Hair, J. F., Black, W. C., Babin, B. J., Anderson, R. E., \& Tatham, R. L. (2006). Multivariate Data Analysis (6th ed.). Upper Saddle River, NJ: Prentice Hall.

Hair, J. F. Jr, Hult, G. T. M., Ringle, C., \& Sarstedt, M. (2016). A primer on partial least squares structural equation modeling (PLS-SEM). Sage Publications.

Hair, J. F. Jr, Sarstedt, M., Hopkins, L., \& Kuppelwieser, V. G. (2014). Partial least squares structural equation modeling (PLS-SEM): An emerging tool in business research. European Business Review.

Henseler, J., Ringle, C. M., \& Sarstedt, M. (2015). A new criterion for assessing discriminant validity in variance-based structural equation modeling. Journal of the Academy of Marketing Science, 43(1), 115-135. doi:10.1007/s11747-014-0403-8

Highhouse, S., Brooks, M. E., \& Gregarus, G. (2009). An organizational impression management perspective on the formation of corporate reputations. Journal of Management, 35(6), 1481-1493. doi:10.1177/0149206309348788

Ho, S. Y., \& Bodoff, D. (2014). The effects of Web personalization on user attitude and behavior: An integration of the elaboration likelihood model and consumer search theory. Management Information Systems Quarterly, 38(2), 497-520. doi:10.25300/MISQ/2014/38.2.08

Hoag, L. A., Bedrosian, J. L., McCoy, K. F., \& Johnson, D. E. (2004). Trade-offs between informativeness and speed of message delivery in augmentative and alternative communication. Journal of Speech, Language, and Hearing Research: JSLHR, 47(6), 1270-1285. doi:10.1044/1092-4388(2004/096) PMID:15842010

Holbrook, M., \& Batra, R. (1987). Assessing the Role of Emotions as Mediators of Consumer Responses to Advertising. The Journal of Consumer Research, 14(3), 404-420. doi:10.1086/209123

Holub, S., Khymytsia, N., Holub, M., \& Fedushko, S. (2020). The Intelligent Monitoring of Messages on Social Networks. CEUR Workshop Proceedings, 2616, 308-317.

Hu, H.-H., Kandampully, J., \& Juwaheer, T. D. (2009). Relationships and impacts of service quality, perceived value, customer satisfaction, and image: An empirical study. Service Industries Journal, 29(2), 111-125. doi:10.1080/02642060802292932

Hu, L. T., \& Bentler, P. M. (1999). Cutoff criteria for fit indexes in covariance structure analysis: Conventional criteria versus new alternatives. Structural Equation Modeling, 6(1), 1-55. doi:10.1080/10705519909540118

Jaakonmäki, R., Müller, O., \& vom Brocke, J. (2017). The impact of content, context, and creator on user engagement in social media marketing. Hawai'i International Conference on Systems Sciences, doi:10.24251/ HICSS.2017.136

Jahn, B., \& Kunz, W. (2012). How to transform consumers into fans of your brand. Journal of Service Management, 23(3), 344-361. doi:10.1108/09564231211248444

Kang, J., Tang, L., \& Fiore, A. M. (2014). Enhancing consumer-brand relationships on restaurant Facebook fan pages: Maximizing consumer benefits and increasing active participation. International Journal of Hospitality Management, 36, 145-155. doi:10.1016/j.ijhm.2013.08.015

Kassim, M. N., \& Souiden, N. (2007). Customer retention measurement in the UAE banking sector. Journal of Financial Services Marketing, 11(3), 217-228. doi:10.1057/palgrave.fsm.4760040

Kenny, D. A., Kaniskan, B., \& McCoach, D. B. (2015). The performance of RMSEA in models with small degrees of freedom. Sociological Methods \& Research, 44(3), 486-507. doi:10.1177/0049124114543236 
Kim, K.-S., \& Sin, S.-C. (2016). Use and evaluation of informatino from social media in the academic context: Analysis of gap between students and librarians. Journal of Academic Librarianship, 42(1), 74-82. doi:10.1016/j. acalib.2015.11.001

Kim, S. S., Lee, J., \& Prideaux, B. (2014). Effect of celebrity endorsement on tourists' perception of corporate image, corporate credibility and corporate loyalty. International Journal of Hospitality Management, 37, 131-145. doi:10.1016/j.ijhm.2013.11.003

Kitchen, P. J., Kerr, G. E., Schultz, D., McColl, R., \& Pals, H. (2014). The elaboration likelihood model: Review, critique and research agenda. European Journal of Marketing, 48(11/12), 2033-2050. doi:10.1108/ EJM-12-2011-0776

Li, C.-Y. (2013). Persuasive messages on information system acceptance: A theoretical extension of elaboration likelihood model and social influence theory. Computers in Human Behavior, 29(1), 264-275. doi:10.1016/j. chb.2012.09.003

Li, Y., \& Wang, X. (2018). Seeking health information on social media: A perspective of trust, selfdetermination, and social support. Journal of Organizational and End User Computing, 30(1), 1-22. doi:10.4018/ JOEUC.2018010101

Lin, H. F. (2007). The Impact of Website Quality Dimensions on Customer Satisfaction in the B2C E-commerce Context. Total Quality Management \& Business Excellence, 18(4), 363-378. doi:10.1080/14783360701231302

Lowry, P. B., \& Gaskin, J. (2014). Partial least squares (PLS) structural equation modeling (SEM) for building and testing behavioral causal theory: When to choose it and how to use it. IEEE Transactions on Professional Communication, 57(2), 123-146. doi:10.1109/TPC.2014.2312452

Mackiewicz, J., \& Yeats, D. (2014). Product Review Users' Perceptions of Review Quality: The Role of Credibility, Informativeness, and Readability. IEEE Transactions on Professional Communication, 57(4), 309-324. doi:10.1109/TPC.2014.2373891

Markus, H., \& Wurf, E. (1987). The dynamic self-concept: A social psychological perspective. Annual Review of Psychology, 38(1), 299-337. doi:10.1146/annurev.ps.38.020187.001503

Martineau, P. (1958). Sharper focus for the corporate image. Harvard Business Review, 36(6), 49-58.

Mastykash, O., Peleshchyshyn, A., Fedushko, S., Trach, O., \& Syerov, Y. (2018, September). Internet social environmental platforms data representation. In 2018 IEEE 13th International Scientific and Technical Conference on Computer Sciences and Information Technologies (CSIT) (Vol. 1, pp. 199-202). IEEE. doi:10.1109/STCCSIT.2018.8526586

Meyer, J. W., \& Rowan, B. (1977). Institutionalized organizations: Formal structure as myth and ceremony. American Journal of Sociology, 83(2), 340-363. doi:10.1086/226550

Nguyen, N., \& Leblanc, G. (2001). Corporate image and corporate reputation in customers' retention decisions in services. Journal of Retailing and Consumer Services, 8(4), 227-236. doi:10.1016/S0969-6989(00)00029-1

Park, C. H., \& Kim, Y. G. (2003). Identifying key factors affecting consumer purchase behavior in an online shopping context. International Journal of Retail \& Distribution Management, 31(1), 16-29. doi:10.1108/09590550310457818

Pavlou, P. A., \& Fygenson, M. (2006). Understanding and predicting electronic commerce adoption: An extension of the theory of planned behavior. Management Information Systems Quarterly, 30(1), 115-143. doi: $10.2307 / 25148720$

Pavlou, P. A., Liang, H., \& Xue, Y. (2007). Understanding and mitigating uncertainty in online exchange relationships: A principal - agent perspective. Management Information Systems Quarterly, 31(1), 105-136. doi: $10.2307 / 25148783$

Petty, R. E., \& Cacioppo, J. T. (1986). Communication and persuasion: Central and peripheral routes to attitude change. Springer. doi:10.1007/978-1-4612-4964-1

Ping, Z. (2013). The affective response model: A theoretical framework of affective concepts and their relationships in the ict context. Management Information Systems Quarterly, 37(1), 247-274. doi:10.25300/ MISQ/2013/37.1.11 
Podsakoff, P. M., MacKenzie, S. B., Lee, J.-Y., \& Podsakoff, N. P. (2003). Common method biases in behavioral research: A critical review of the literature and recommended remedies. The Journal of Applied Psychology, 88(5), 879-903. doi:10.1037/0021-9010.88.5.879 PMID:14516251

Preacher, K. J., Rucker, D. D., \& Hayes, A. F. (2007). Addressing moderated mediation hypotheses: Theory, methods, and prescriptions. Multivariate Behavioral Research, 42(1), 185-227. doi:10.1080/00273170701341316 PMID:26821081

Qureshi, I., \& Compeau, D. (2009). Assessing between-group differences in information systems research: A comparison of covariance-and component-based SEM. Management Information Systems Quarterly, 33(1), 197-214. doi:10.2307/20650285

Ramanan, R. (2015). Promoting informativeness via staggered information releases. Review of Accounting Studies, 20(1), 537-558. doi:10.1007/s11142-014-9307-6

Reinartz, W., Haenlein, M., \& Henseler, J. (2009). An empirical comparison of the efficacy of covariance-based and variance-based SEM. International Journal of Research in Marketing, 26(4), 332-344. doi:10.1016/j. ijresmar.2009.08.001

Sarstedt, M., Hair, J. F., Ringle, C. M., Thiele, K. O., \& Gudergan, S. P. (2016). Estimation issues with PLS and CBSEM: Where the bias lies! Journal of Business Research, 69(10), 3998-4010. doi:10.1016/j. jbusres.2016.06.007

Schlenker, B. R. (1980). Impression Management: the self-concept, social identity, and interpersonal relations. Brooks/Cole.

Shook, C. L., Ketchen, D. J. Jr, Hult, G. T. M., \& Kacmar, K. M. (2004). An assessment of the use of structural equation modeling in strategic management research. Strategic Management Journal, 25(4), 397-404. doi:10.1002/smj.385

Sin, S.-C. (2016). Social media and problematic everyday life information-seeking outcomes: Differences across use frequency, gender, and problem-solving styles. Journal of the Association for Information Science and Technology, 67(8), 1793-1807. doi:10.1002/asi.23509

Spagnoletti, P., Resca, A., \& Sæbø, Ø. (2015). Design for social media engagement: Insights from elderly care assistance. The Journal of Strategic Information Systems, 24(2), 128-145. doi:10.1016/j.jsis.2015.04.002

Staw, B. M. (1991). Dressing up like an organization: When psychological theories can explain organizational action. Journal of Management, 17(4), 805-819. doi:10.1177/014920639101700412

Susssman, S. W., \& Siegal, W. S. (2003). Informational Influence in Organizations: An Integrated Approach to Knowledge Adoption. Information Systems Research, 14(1), 47-65. doi:10.1287/isre.14.1.47.14767

Swani, K., Milne, G. R., Brown, B. P., Assaf, A. G., \& Donthu, N. (2017). What messages to post? Evaluating the popularity of social media communications in business versus consumer markets. Industrial Marketing Management, 62, 77-87. doi:10.1016/j.indmarman.2016.07.006

Tsai, W.-H. S., \& Men, L. R. (2013). Motivations and Antecedents of Consumer Engagement With Brand Pages on Social Networking Sites. Journal of Interactive Advertising, 13(2), 76-87. doi:10.1080/15252019.2013.826549

Vid, I. (2016). The Image Crisis Of The Organization. Professional Communication and Translation Studies, (9), 27-34.

Wakefield, R., \& Wakefield, K. (2016). Social media network behavior: A study of user passion and affect. The Journal of Strategic Information Systems, 25(2), 140-156. doi:10.1016/j.jsis.2016.04.001

Whetten, D. A., Felin, T., \& King, B. G. (2009). The practice of theory borrowing in organizational studies: Current issues and future directions. Journal of Management, 35(3), 537-563. doi:10.1177/0149206308330556

Wilson, C. (1980). The nature of equilibrium in markets with adverse selection. The Bell Journal of Economics, 11(1), 108-130. doi:10.2307/3003403

Wu, W., West, S. G., \& Taylor, A. B. (2009). Evaluating model fit for growth curve models: Integration of fit indices from SEM and MLM frameworks. Psychological Methods, 14(3), 183-201. doi:10.1037/a0015858 PMID:19719357 
Zellner, A. (1962). An efficient method of estimating seemingly unrelated regressions and tests for aggregation bias. Journal of the American Statistical Association, 57(298), 348-368. doi:10.1080/01621459.1962.10480664

Zha, X., Li, J., \& Yan, Y. (2015). Advertising value and credibility transfer: Attitude towards web advertising and online information acquisition. Behaviour \& Information Technology, 34(5), 520-532. doi:10.1080/0144 929X.2014.978380

Zha, X., Yang, H., Yan, Y., Liu, K., \& Huang, C. (2018). Exploring the effect of social media information quality, source credibility and reputation on informational fit-to-task: Moderating role of focused immersion. Computers in Human Behavior, 79, 227-237. doi:10.1016/j.chb.2017.10.038

Zhang, L., \& Peng, T.-Q. (2015). Breadth, depth, and speed: Diffusion of advertising messages on microblogging sites. Internet Research, 25(3), 453-470. doi:10.1108/IntR-01-2014-0021

Zhou, T. (2012). Understanding users' initial trust in mobile banking: An elaboration likelihood perspective. Computers in Human Behavior, 28(4), 1518-1525. doi:10.1016/j.chb.2012.03.021

Soo II Shin is an Assistant Professor of Information Systems for the College of Business at Kennesaw State University. He earned his Ph.D. in Management Information Systems from Auburn University. His research interests are in the areas of smart tourism, computer-mediated communication, virtual community, blockchain, and trust concerns in the context of e-media. His publications appear in Information \& Management, Telematics and Informatics, Asia Pacific Journal of Information Systems, and other premier journals. He has also authored many conference proceedings, and his works have been presented at prestigious national and international MIS/ IS conferences.

Dianne Hall is a Torchmark Professor of Information Systems and Analytics at Auburn University. She holds a doctorate in Information and Operations Management from Texas A\&M University. Her work appears in academic and practitioner journals such as the Journal of the Association for Information Systems, Strategic Entrepreneurship, International Journal of Logistics Management, International Journal of Physical Distribution and Logistics Management, Decision Support Systems, Communications of the Association for Information Systems, and others. Her work has also appeared in several books. Her current research interests include applications of information technologies in support of decision processes, smart cities, logistics, healthcare, supply chain resiliency, and contingency planning.

Sumin Han is an assistant professor in the Department of Systems and Technology at the Raymond J. Harbert College of Business. Her current research focuses on dynamic panel data analysis, joint models, consumer behavior, and international business research. Her work has appeared in journals such as Journal of the Association for Information Systems, Journal of Business Research, Public Administration Review, and European Journal of Marketing.

David Paradice is the Harbert Eminent Scholar in Information Systems \& Analytics in the Raymond J. Harbert College of Business. He has worked as a programmer and consultant and was involved in building one of the first interactive DSS used in the electric utility industry. Dr. Paradice has published articles and book chapters focusing on the use of technology in support of managerial problem formulation. His publications appear in Journal of MIS, IEEE Transactions on Systems, Man \& Cybernetics, Decision Sciences, Communications of the ACM, Decision Support Systems, Annals of Operations Research, Journal of the AIS, Journal of Business Ethics, and other journals. He has been active in the Association of Information Systems and the International Federation on Information Processing. He has been a Senior Associate Dean, Center Director, and teaching award winner. He has also served on corporate advisory boards.

Teresa Lang has 15 years of public accounting experience including working with two of the largest CPA firms in the country, a few small local firms, and civil service overseas. She has worked in both taxation and audit, and has worked for CPA firms in Kansas, California, Alaska, and Florida. Her Bachelor's Degree is from the University of Florida, and her Masters of Accountancy and PhD are from Auburn University. From 2015-2019, Teresa was one of ten CPA members in the country selected to assist with the review and renovation of the Business Environment and Concepts (BEC) section of the CPA exam. Dr. Lang is an awarding winning teacher and an accounting Professor at Auburn University at Montgomery. She has presented her research at many conferences across the nation, and has several academic journal publications and proceedings. Her passion is teaching with the hope of helping the next generation of accountants succeed in the workplace. 